\title{
Efektivitas Aplikasi Sipadlih Pada Sosialisasi Pemilihan Walikota Dan Wakil Walikota Padang Tahun 2018
}

\author{
Dicki Zeparianto', M. Fachri Adnan² \\ 1,2Universitas Negeri Padang \\ Email : dickizeparianto18@gmail.com, fachriadnan@fis.unp.ac.id
}

\begin{abstract}
Abstrak
Penelitian ini dilatarbelakangi dari angka golput yang cukup tinggi terjadi pada pemilihan walikota dan wakil walikota Padang tahun 2008 mencapai 43\%, 2013 46\%. Pada umumnya masyarakat kota padang lebih suka menggunakan smartphoonenya dalam mencari informasi. Berdasarkan hal tersebut KPU kota padang menciptakan aplikasi SiPadlih untuk mempermudah sosialisasi. Penelitian ini menggunakan teknik kualitatif deskriptif. Informan dipilih menggunakan teknik purposive sampling dan incidental sampling. Teknik pengumpulan data dengan wawancara dan dokumentasi. Uji keabsahan data dengan cara trianggulasi dan member check. Kesimpulan penelitian ini, bahwa pelaksanaan aplikasi SiPadlih belum efektif. Hal ini terbukti masih banyak masyarakat kota Padang yang belum mengetahui dengan adanya aplikasi SiPadlih. Jumlah warga yang telah mendownload aplikasi SiPadlih hanya sekitar 100 orang. Hal ini dikarenakan tidak dilakukan sosialisasi secara tidak langsung mengenai aplikasi SiPadlih, disebabkan tidak adanya anggaran khusus untuk mensosialisasikan aplikasi SiPadlih. Selanjutnya terdapat informasi yang tidak bisa dipahami dalam aplikasi SiPadlih.
\end{abstract}

Kata kunci: KPU kota Padang, Aplikasi SiPadlih, Sosialisasi, Efektivitas

\begin{abstract}
This research is motivated by a high number of abstentions occurring in the election of mayors and vice mayors of Padang in 2008 reaching 43\%, 2013 46\%. In general, the city of Padang people prefer to use their smartphone in searching for information. Based on this, KPU Padang City created the SiPadlih application to facilitate socialization. This study uses descriptive qualitative techniques. Informants were selected using purposive sampling and incidental sampling techniques. The technique of collecting data with interviews and documentation. Test the validity of the data by triangulation and member check. The conclusion of this study, that the implementation of the SiPadlih application has not been effective. It is proven that there are still many people in the city of Padang who do not know about the SiPadlih application. The number of people who have downloaded the SiPadlih application is only around 100 people. This is because there is no indirect socialization of the SiPadlih application, due to the absence of a special budget to socialize the SiPadlih application. Furthermore, there is information that cannot be understood in the SiPadlih application.
\end{abstract}

Keywords: KPU Padang city, SiPadlih Application, Socialization, Effectiveness

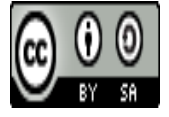

Received: July 25, $2019 \quad$ Revised: July 30, $2019 \quad$ Available Online: July 31, 2019 


\section{Pendahuluan}

Sosialisasi politik merupakan suatu proses melakukan pemahaman konsep, nilai-nilai, ide, pengetahuan, sikap dan prilaku untuk memunculkan keiikutsertaan atau partisipasi efektif didalam kelompok atau institusi politik (Putra, 2016). Sosialisasi dalam pemilihan umum bertujuan menyebarluaskan informasi mengenai tahapan, jadwal, program pemilihan pilkada serta meningkatkan pengetahuan, pemahaman, kesadaran masyarakat tentang hak dan kewajiban dalam pilkada dan juga meningkatkan partisipasi pemilih dalam pemilihan kepala daerah. Sosialisasi pemilihan walikota dan wakil walikota kota Padang pada tahun 2018 menggunakan dua cara, yaitu dengan cara langsung dan tidak langsung. Sosialisasi cara langsung yang dilakukan oleh KPU kota Padang yaitu pertemuan dengan masyarakat. Sosisalisasi secara tidak langsung dengan menggunakan media massa seperti aplikasi infomasi, website, koran, radio, TV, dan juga spanduk.

Cara terbaru yang dilakukan untuk sosialisasi tidak langsung adalah dengan menggunakan aplikasi Sistem Informasi Padang Memilih (SiPadlih). Aplikasi Sistem Informasi Padang Memilih (SiPadlih) berisikan informasi tentang mengenai pemilihan walikota, agar masyarakat yang membaca bisa mengikuti informasi pemilihan walikota dan wakil walikota Padang tahun 2018. Aplikasi SiPadlih diciptakan dengan berbagai alasan yaitu angka golput yang cukup tinggi terjadi pada pemilihan walikota dan wakil walikota padang tahun 2008 mencapai $43 \%$, tahun 2013 menacapai 46\%, dan masyarakat kota Padang pada umunya lebih memanfaatkan handphone atau gadgetnya sebagai sumber pencarian informasi yang cukup besar dalam penggunannya. Selain itu KPU Kota Padang sangat membidik partispasi pemilih pemula dan pemilih milenial yang sangat akrab dalam penggunaan smartphonenya. Sehingga KPU kota Padang berpikir inovatif dan kreatif dengan cara menciptakan aplikasi Sistem Informasi Padang Memilih (SiPadlih) sebagai pemberian informasi tentang pemilihan walikota.

Aplikai SiPadlih baru diterapkan dalam jangka waktu yang singkat, untuk itu perlu dilihat keefektifann pelaksanaan aplikasi SiPadlih, Karena masih terdapat kekurangan dalam aplikasi dan pelaksanaanya. Seperti masyarakat kota Padang masih banyak yang belum mengetahui dengan adanya aplikasi SiPadlih, hanya sekitar 100 orang yang telah mendownload aplikasi SiPadlih. Hal ini dikarenakan sosilaisasi aplikasi SiPadlih yang masih minim, karena sosialisasi aplikasi SiPadlih hanya dilakukan dengan sosialisasi secara langsung. Seharusnya sosialisasi juga dilakukan dengan cara tidak langsung dengan menggunakan media cetak, media sosial, agar sosialisasi aplikasi SiPadlih tersebar secara maksimal. Selanjutnya tidak adanya anggaran khusus untuk sosialisasi aplikasi SiPadlih. Kemudian konten atau informasi yang dimuat dalam aplikasi SiPadlih kurang lengkap.

Sesuai dengan masalah diatas, maka penelitian ini bertujuan untuk mengetahui bagaimana efektivitas aplikasi SiPadlih pada sosialisasi pemilihan walikota dan wakil walikota Padang tahun 2018. Manfaat penelitian: pertama, agar penelitian ini bisa menjadi sumber informasi. Kedua, hasil penelitian ini dapat menjadi masukan bagi KPU kota Padang dalam mensosialisasikan pelaksanaan aplikasi SiPadlih. Ketiga, selain untuk menambah wawasan dan pengetahuan tentang pelaksanaan aplikasi SiPadlih dalam peningkatan efektivitas sosialisasi, dapat digunakan sebagai bahan referensi atau informasi ilmiah untuk penelitian-penelitian berikutnya.

Sosialisasi sebagai suatu proses interaksi sosial dengan orang untuk memperoleh pengetahuan, sikap, nilai, dan perilaku essensial untuk keikutsertaan (partisipasi) efektif dalam masyarakat (James W. Vander Zanden dalam Damsar 2012). Kemudian menurut Thio (Damsar 2012) sosialisasi politik yaitu proses dengan mana individu-individu memperoleh pengetahuan, kepercayaan-kepercayaan, dan sikap politik. Berdasarkan pengertian tersebut, dapat dikatakan 
bahwa dalam proses sosialisasi politik ada suatu upaya yang dilakukan oleh seseorang atau kelompok guna memberikan suatu penanaman atau internalisasi suatu gagasan atau nilai-nilai politik kepada orang lain (masyarakat) agar nantinya memunculkan suatu sikap politik (partispasi) kepada masyarakat atau institusi.

Adapun isi sosialisasi politik menurut Efriza (2012), bahwa isi sosialisasi politik yang disampaikan oleh seorang individu atau agen sosialisasi kepada individu atau kelompok masyarakat sebagai berikut: a) Informasi politik, Informasi politik adalah isi sosialisasi yang memberikan penerangan tentang terjadinya suatu peristiwa politik. b) Pemberian keyakinan dan kepercayaan politik, Agen sosialisasi akan begitu kerasnya memaksakan kehendak, citacita, firasat atau ideology politiknya. c) Pengetahuan politik, Pengetahuan politik sangat terkait dengan pemahaman akademis terhadap fenomena politik, artinya fenomena politik diberikan secara terstruktur dalam bentuk kurikulum pendidikan.

Efektivitas berarti bahwa tujuan yang telah direncanakan sebelumnya dapat tercapai atau dengan kata sasaran tercapai karena adanya proses kegiatan. Sedangkan pendapat lain mengenai pengertian efektivitas sebagaimana yang dikemukakan oleh Drucker (Moenir,2006:166) mengenai efektivitas adalah melakukan atau mengerjakan sesuatu dengan tepat pada sasaran (doing the right thing). Dari pendapat diatas mengenai pengertian efektivitas maka yang menjadi penekanan dari pengertian efektivitas ini berada pada pencapaian tujuan atau sasaran yang dikehendaki dapat tercapai sesuai dengan rencana semula dan menimbulkan dampak terhadap apa yang diinginkan atau diharapkan.

Adapun kriteria atau ukuran mengenai pencapaian tujuan efektif atau tidak, sebagaimana dikemukakan oleh Gibson (Tangkilisan 2005:64) mengemukakan kriteria efektivitas organisasi yang terdiri dari lima unsur: a) Kejelasan tujuan yang hedak dicapai, hal ini dimaksudkan supaya pegawai dalam melaksanakan tugas dapat mencapai sasaran yang terarah serta tercapainya tujuan dari organisasi. b) ketepatan program, suatu rencana yang baik perlu dijabarkan dalam pelaksanaan program-program yang dilakukan. Pelaksanaan program harus sesuai dengan permasalahan serta tepat sasaran. c) Kejelasan strategi pencapaian tujuan, diketahui bahwa strategi adalah jalan yang diikuti sebagai bentuk upaya dalam mencapai sasaran-sasarn yang ditentukan agar para implementer tidak salah arah dalam pencapaian tujuan. d) Tersedianya sarana dan prasarana, salah satu indikator efektivitas ialah kemampuan bekerja secara produktif. Dengan sarana dan prasarana yang baik akan meningkatkan efektivitas dan juga produktivitas organisasi. e) Proses analisis dan perumusan, berkaitan dengan tujuan yang hendak dicapai dan strategi yang telah ditetapkan artinya ialah kebijakan harus mampu menjembatani tujuan-tujuan dengan usaha pelaksanaan kegiatan operasional.

\section{Metodologi Penelitian}

Penelitian ini merupakan sebuah penelitian deskriptif dengan pendekatan kualitatif. Informan penelitian dipilih menggunakan teknik purposive sampling yaitu penarikan informan yang dilakukan dengan sengaja serta teknik incidental sampling yaitu siapa saja yang secara kebetulan bertemu dengan peneliti dapat digunakan sebagai informan. Penelitian ini dilaksanakan di KPU kota Padang dan wilayah kota Padang. Alat bantu dalam penelitian ini menggunakan pedoman wawancara, buku catatan, alat rekam, peneliti dan alat foto. Data yang digunakan yaitu data primer dan skunder yaitu data yang berasal dari wawancara dan dokumentasi. Data ini diuji keabsahannya dengan teknik triangulasi, yaitu dengan membandingkan hasil pengamatan dengan hasil wawancara. Data ini kemudian dianalisis dengan teknik analisis data kualitatif mulai dengan reduksi data, penyajian data hingga penarikkan kesimpulan.

\section{Hasil Penelitian dan Pembahasan}


Aplikasi Sistem Informasi Padang Memilih (SiPadlih) adalah aplikasi yang berisikan informasi mengenai pemilihan walikota dan wakil walikota Padang tahun 2018, kemudian aplikasi SiPadlih merupakan sebuah inovasi dalam sosialisasi untuk menyebarkan informasi mengenai pemilihan walikota dan wakil walikota Padang tahun 2018. Aplikasi ini digagas oleh Kasubag Teknis KPU Kota Padang, yakni bapak Sutrisno, SE. Adapun tujuan dalam pembuatan aplikasi SiPadlih yaitu, untuk menambah pengetahuan masyarakat kota Padang khususnya tentang informasi pemilihan walikota dan wakil walikota Padang tahun 2018, kemudian aplikasi SiPadlih dapat memudahkan KPU kota Padang dalam menyampaikan informasi mengenai pemilihan walikota dan wakil walikota Padang. Pembuatan aplikasi SiPadlih dilakukan oleh bapak Geo Fanne Farell yang menjabat sebagai direktur PT. Aka Solusi Teknologi dengan biaya Rp. 39.600 .000 berdasarkan Surat Perjanjian Kerja (SPK) no 06/SPK/III/2017. SiPadlih dirancang sebagai jendela informasi berbasis aplikasi bagi warga Kota Padang dan dapat diunduh dengan mudah melalui kanal play store dan app store. Berikut adalah gambar aplikasi SiPadlih:

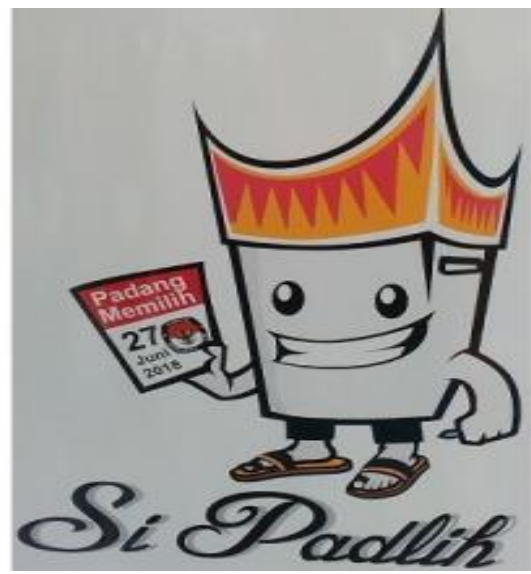

Gambar 1. Aplikasi SiPadlih

Tampilan aplikasi ini menggunakan warna orange dengan warna latar belakang putih. Pada aplikasi ini terdapat enam menu utama, setiap menu utama memiliki beberapa sub menu yakni:

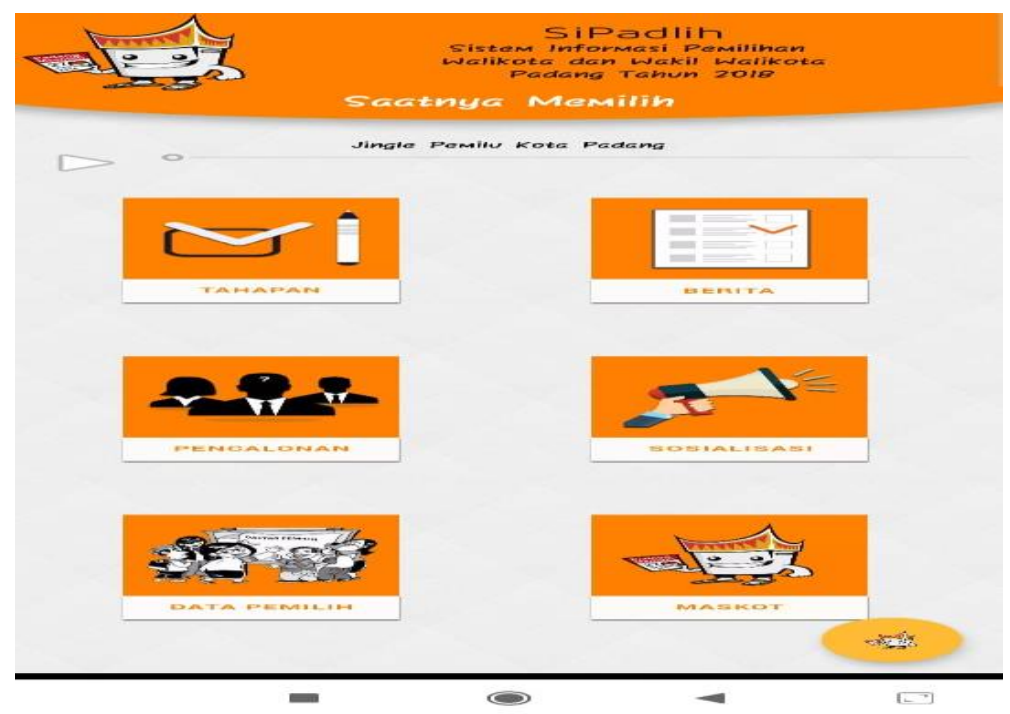

Gambar 2. Menu Utama SiPadlih 


\section{Tahapan Pemilihan}

\section{Persiapan}

(1) Perencanaan program dan anggrana, (2) Penyusunan dan penandatanganan NDHP, (3) Penyusunan dan pengesahan peraturan penyelenggraan pemilihan, (4) Sosialisasi, (5) Pembentukan PPK, PPS, dan KPPS, (6) Pendaftaran pemantauan pemilih, pengolahan DP4, (7) Pemutakhiran data dan daftar pemilih

\section{Penyelenggaraan}

Syarat dukungan pasangan calon, Pendaftaran pasangan calon, Sengketa TUN pemilihan, Masa kampanye, Laporan audit dana kampanye, Pengadaan dan pendistribusian perlengkapan pemungutan dan perhitungan suara, Pemungutan dan perhitungan, Rekapitulasi hasil penghitungan suara, Penetapan paslon terpilih tanpa permohonan perselisihan hasil pemilihan, Sengketa perselisihan hasil pemilihan, Penetapan pasangan calon terpilih paska putusan MK, Pengusulan pengesahan pengangkatan pasangan calon terpilih, Evaluasi dan pelaporan tahapan

\section{Berita}

Pada sub menu ini berisi tentang berita-berita seputar pemilihan umum

1. Pencalonan
a. Perorangan
Pada sub menu ini berisi tentang persyaratan perseorangan
b. Parpol
Pada sub menu ini berisi tentang persyaratan partai politik

2. Sosialisasi
a. Sejarah dan penyelenggaraan
Pada sub menu ini berisi tentang sejarah penyelenggara pemilu
b. Daerah pemilihan
Pada sub menu ini berisi tentang daerah pemilihan kota Padang
c. Pentingnya pemilu
Pada sub menu ini berisi tentang pentingnya pemilu
d. Pemungutan dan perhitungan suara
Pada sub menu ini berisi tentang cara pemungutan dan penghitungan suara
e. Tempat pemungutan suara
Pada sub menu ini berisi tentang denah tempat pemungutan suara
f. Denah perhitungan suara
Pada sub menu ini berisi tentang denah penghitungan suara
g. Profil
Pada sub menu ini berisi tentang profil komisioner KPU Kota Padang 2013-2018

3. Data Pemilih

Pada menu ini berisi tentang pemutakhiran data pemilih, syarat sebagai pemilih, dan tahapan pemutakhiran data pemilih

4. Maskot

Pada menu ini berisi menjelaskan arti dari mascot aplikasi SiPadlih dan berisi lirik jingle aplikasi SiPadlih

Untuk melihat sosialisasi aplikasi SiPadlih berjalan sesuai dengan tujuan targetnya, maka perlu dilihat dari indicator sosialisasi politik menurut Menurut Efriza (2012), bahwa isi sosialisasi politik yang disampaikan oleh seorang individu atau agen sosialisasi kepada individu atau kelompok masyarakat sebagai berikut: 
Pertama, memberikan informasi politik yaitu isi sosialisasi yang memberikan penerangan tentang terjadinya suatu pristiwa politik. Namun hasil yang ditemukan dalam penelitian ini yaitu, ketertarikan masyarakat untuk mengenal aplikasi SiPadlih masi minim, karena masyarakat masih kurang tertarik untuk memanfaatkan aplikasi SiPadlih dan penerapan dari aplikasi SiPadlih yang masih minim. Selanjutnya masyarakat yang telah mengetahui dengan aplikasi SiPadlih juga memberikan kritikan, seperti konten yang dimuat dalam aplikasi masi banyak berupa tulisan atau monoton, sehingga dapat mengurangi minat dari pembaca dan informasi yang dimuat juga perluh ditambahkan seperti penambahan profil pasangan calon walikota.

Kedua, pemberian keyakinan dan kepercayaan informasi politik, yaitu agen sosialisasi akan begitu kerasnya memaksakan kehendak, cita-cita, firasat atau ideology politiknya. Hasil yang didapatkan dalam penelitian yaitu terdapat tanggapan masyarakat mengenai isi yang dimuat dalam aplikasi SiPadlih juga dapat dipercaya karena informasi yang dimuat dari KPU kota Padang sendiri yang mengelolah.

Ketiga, pengetahuan politik, yaitu pengetahuan politik sangat terkait dengan pemahaman akademis terhadap fenomena politik, artinya fenomena politik diberikan secara terstruktur. Hasil yang ditemukan saat penelitian yaitu masyarakat yang mengetahui dengan aplikasi SiPadlih juga memberikan pernyataan, seperti informan semakin paham dengan informasi pilwako kota Padang, setelah informan membaca isi dari aplikasi dan informan juga menemukan informasi yang tidak bisa dipahami, karena infomasi yang dimuat belum terisi.

Guna dapat memaksimalkan proses sosialisasi aplikasi SiPadlih, KPU kota Padang dituntut agar dapat mensosialisasikan dengan maksimal, agar masyarakat kota Padang mengetahui dengan adanya aplikasi SiPadlih tersebut. Maka untuk melihat sejauh mana keefektivan aplikasi SiPadlih harus di ukur dengan menggunakan indicator yang di kemukakan oleh Gibson (Tangkilisan, 2005) yaitu dengan melihat kejelasan tujuan yang akan di capai, ketepatan program, kejelasan strategi yang dimiliki, tersedianya sarana dan prasarana serta proses analisis dan perumusan.

Pertama, tujuan yang hendak dicapai, hal ini dimaksudkan supaya KPU dalam melaksanakan sosialisasi aplikasi SiPadlih dapat mencapai sasaran yang terarah serta tercapainya tujuan. Berdasarkan hasil wawancara yang dilakukan peneliti, bahwasannya aplikasi SiPadlih untuk sosialisasi agar menambah pengetahuan masyarakat mengenai pemilihan walikota dan wakil walikota kota Padang, terhadap pemilih pemula, pemilih milenial/warga net khususnya dan pada umumnya untuk seluruh warga kota Padang. Agar mereka dapat mengikuti informasi pemilihan walikota dan wakil walikota denga update dan juga untuk meningkatkan tingkat partisipasi pada pemilihan walikota dan wakil walikota kota Padang 2018.

Kedua, ketepatan program, yaitu pelaksanaan program harus sesuai dengan permasalahan serta tepat sasaran. Hasil penelitiian ini, aplikasi SiPadlih diciptakan dengan alasan berdasarkan angka golput yang cukup tinggi terjadi pada pemilihan walikota dan wakil walikota padang tahun 2008 yang menacapai 43\%, tahun 2013 mencapai $46 \%$. Dan masyarakat kota Padang pada umunya lebih memanfaatkan handphone atau gadgetnya sebagai sumber pencarian informasi yang cukup besar dalam penggunannya terutama para kaum milenial atau warga net.

Ketiga, kejelasan strategi pencapaian tujuan. yaitu jalan yang diikuti sebagai bentuk upaya dalam mencapai sasaran-sasarn yang ditentukan agar para implementer tidak salah arah dalam pencapaian tujuan. Dari hasil penelitian bahwa strategi yang dilakukan oleh KPU kota Padang untuk mensosialisasikan aplikasi SiPadlih yaitu dengan cara mengadakan suatu acara kegiatan sosialisasi yang dihadiri oleh kalangan masyarakat dan stakeholder kota Padang dan didalam kegiatan sosialisasi tersebut juga disampaikan bahwasanya KPU kota Padang telah memiliki aplikasi SiPadlih, dan mengajak masyarakat untuk mendownloadnya. Kemudian untuk sosialisasi aplikasi SiPadlih yang secara khusus tidak ada dilakukan oleh KPU kota Padang, KPU 
hanya mensosialisasikannya dibarengin dengan sosialisasi seperti biasanya. Selanjutnya KPU kota Padang juga melakukan kerja sama dengan lembaga lainnya seperti, LSM karang taruna kota Padang, para pihak kampus, dan sekolah - sekolah yang ada di kota Padang.

Keempat, sarana dan prasarana. Salah satu faktor pendukung tercapainya tujuan dari aplikasi SiPadlih adalah tersedianya saran dan prasarana yang memadai untuk menunjang efektivitas pelaksanaan aplikasi SiPadlih. Kendala dari segi sarana dan prasarana adalah tidak adanya sosialisasi secara khusus untuk aplikasi SiPadlih baik secara langsung atau tidak langsung, seperti pemasangan spanduk, poster, baliho dan sebagainya. Dikarenakan tidak adanya anggaran khusus untuk sosialisasi aplikasi SiPadlih. Sedangkan anggaran Rp. 39.600.000 hanya untuk pembuatan aplikasinya saja.

Kelima, analisis dan perumusan, yaitu berkaitan dengan tujuan yang hendak dicapai dan strategi yang telah ditetapkan artinya ialah kebijakan harus mampu menjembatani tujuantujuan dengan usaha pelaksanaan kegiatan operasional. Hasil analisis dan perumusan pada penelitian ini yaitu, KPU kota Padang mengharapkan masyarakat kota Padang dapat memanfaatkan aplikasi SiPadlih ini dalam pencarian informasi mengenai pemilukada kota Padang 2018.

\section{Pembahasan}

Sosialisai aplikasi SiPadlih dalam memberikan informasi pilwako kota Padang berdasarkan pendapat/pandangan masyarakat dapat dilihat dari beberapa indicator yaitu menurut Efriza (2012) a) memberikan informasi, b) pemberian keyakinan dan kepercayaan informasi, c) pengetahuan politik.

Pertama, memberikan informasi, berdasarkan temuan hasil dapat dikatakan bahwa ketertarikan masyarakat untuk mengenal aplikasi SiPadlih masi minim, karena disebabkan masyarakat masih kurang tertarik utnuk memanfaatkan aplikasi SiPadlih, selanjutnya penerapan dari aplikasi SiPadlih yang masih minim mengakibatkan masyarakat masih banyak yang belum mengetahui dengan adanya aplikasi SiPadlih, hal ini disebabkan karena sosialisasi aplikasi SiPadlih hanya dilakukan dengan cara langsung saja, seperti mengadakan pertemuan dengan berbagai kalangan msyarakat di kota Padang, seharusnya sosialisasi secara tidak langsung juga diterapkan seperti pemasangan spanduk, baliho, pamphlet dan sebagainya. Kemudian masyarakat yang telah mengetahui dengan aplikasi SiPadlih juga memberikan kritikan, seperti konten yang dimuat dalam aplikasi masi banyak berupa tulisan atau monoton, sehinggan dapat mengurangi minat dari pembaca dan informasi yang dimuat juga perluh ditambahkan seperti penambahan profil pasangan calon walikota.

Kedua, pemberian keyakinan dan kepercayaan informasi, hasil yang ditemukan yaitu tanggapan masyarakat mengenai isi yang dimuat dalam aplikasi SiPadlih juga dapat dipercaya karena informasi yang dimuat dari KPU kota Padang sendiri yang mengelolah.

Ketiga, pengetahuan politik, berdasarkan hasil temuan masih banyak masyarakat kota padang yang belum mengetahui dengan adanya aplikasi SiPadlih ini. Kemudian masyarakat yang mengetahui dengan aplikasi SiPadlih juga memberikan pernyataan seperti informan semakin paham dengan infomasi pilwako setelah informan membaca isi dari aplikasi dan informan juga menemukan informasi yang tidak bisa dipahami seperti yang terdapat dimenu tahapan persiapan dan penyelengaraan dan dimenu data pemilih, karena infomasi yang dimuat belum terisi. Dan perluh juga ada tambahan profil pasangan calon walikota dan wakil walikota agar masyarakat lebih mengenal dengan pilihannya.

Analisis Efektivitas sosialisasi aplikasi Sistem Informasi Padang Memilih (SiPadlih) dalam meningkatkan pengetahuan masyarakata pada pilwako dan partisipasi pemilih dapat dilihat dari beberapa indikator Menurut Gibson (Tangkilisan 2005:64) yaitu a) Tujuan yang 
hendak dicapai b) ketepatan program c) Kejelasan Strategi d) Tersedianya sarana dan prasarana e) Proses Analisis dan Perumusan.

Pertama, tujuan yang hendak dicapai, pada indikator ini peneliti ingin melihat sejauh mana tujuan yang sudah ditetapkan oleh pelaskasanaan sosialisasi aplikasi SiPadlih dapat dicapai serta sejauh mana tujuan tersebut dapat mewujudkan efektivitas pelaksanaan sosialisasi aplikasi SiPadlih dalam meningkatkan pengetahuan masyarakat kota Padang pada pemilihan umum. tujuan dari pelaksanaan sosialisasi aplikasi SiPadlih sudah terarah dengan baik serta didukung dengan pelaksanaan kegiatan yang dimiliki sebagai bentuk sosialisasi peilwako. Pelakasanaan sosialisasi aplikasi SiPadlih yang dilakukan pada KPU kota Padang dalam pemberian informasi mengenai pemilihan walikota dan wakil walikota Padang, penerapan aplikasi SiPadlih ini yang telah dilakukan bertujuan agar pengetahuan masyarakat mengenai peilwako semakin bertambah, sehingga meningkatkan pertisipasi pemilih dalam pemilihan kepala daerah walikota dan wakil walikota Padang tahun 2018. Namun yang menjadi kendala ialah masih banyak masih banyak masyarakat kota Padang yang belum mengetahui denngan adanya aplikasi SiPadlih ini, khususnya para masyarakat milenial/warga net. Hal ini dikarenkaan kegiatan sosialisasi yang belum maksimal yang dilakukan oleh KPU kota Padang, terutama sosialisasi secara tidak langsung mengenai aplikasi SiPadlih. Sebaiknya sosialisasi juga dilakukan dengan secara tidak langsung, seperti pemasangan spanduk, poster, dan baliho, agar masyarakat kota Padang mengetahui dengan adanya apliksi SiPadlih.

Hal ini sejalan dengan hasil penelitian yang dilakukan oleh Ratnamulyani dan Maksudi (2018) tentang Peran Media Sosial Dalam Peningkatan Partisipasi Pemilih Pemula Dikalangan Pelajar di Kabupaten Bogor. Hasil dari penelitian terdahulu ialah Para politisi di Kabupaten Bogor belum mampu mengoptimalkan pemanfaatkan aplikasi media sosial berbasis internet untuk kepentingan kampanye dalam rangka peningkatan partisipasi pemilih pemula dari kalangan pelajar, yang dikarenakan para pelajar masih banyak yang belum mengetahui dengan adanya informasi pemilu yang ada di media sosial.

Kedua, ketepatan program, Pada indikator ini peneliti ingin mengetahui berdasarkan apa aplikasi SiPadlih dibuat, agar pembuatan aplikasi SiPadlih tetap pada sasarannya. Aplikasi SiPadlih diciptakan dengan berdasarkan alasan yaitu masyarakat kota Padang pada umunya lebih memanfaatkan handphone atau gadgetnya sebagai sumber pencarian informasi yang cukup besar dalam penggunannya terutama para kaum milenial atau warga net, kemudian angka golput yang cukup tinggi terjadi pada pemilihan walikota dan wakil walikota padang tahun 2013 yang menacapai 46\%. Maka dari itu KPU berinesiatif untuk menciptakan trobosan dengan menciptakan sebuah aplikasi SiPadlih tersebut, dan disamping itu dengan adanya aplikasi SiPadlih ini juga lebih memudahkan KPU dalam bersosialisasi.

Hal ini sejalan dengan hasil penelitian yang dilakukan oleh Ratnamulyani dan Maksudi (2018) tentang Peran Media Sosial Dalam Peningkatan Partisipasi Pemilih Pemula Dikalangan Pelajar di Kabupaten Bogor. Hasil dari penelitian tersebut bahwa seiring dengan perkembangan teknologi informasi berbasis internet, maka semakin penting peran media sosial online sebagai salah satu faktor yang dapat memberikan efek positif dalam peningkatan partisipasi politik dengan menambahnya pengetahuan informasi pemilu dikalangan pelajar sebagai pemilih pemula.

Ketiga, kejelasan strategi dalam pencapaian tujuan, yaitu menjelaskan bahwa strategi merupakan jalan atau cara yang diikuti dalam berbagai upaya dalam mencapai sasaran-sasaran yang ditentukan agar para implementer tidak tersesat dalam pencapaian tujuan. Strategi yang dibangun oleh KPU kota Padang adalah menjalin kerjasama yang baik antara seluruh stakeholder yang berkaitan seperti, lembaga swadaya masyarakat, pihak kampus dan sekolah. Hal ini dilakukan agar sosialiasi pemilu dapat berjalan dengan baik. Namun yang menjadi kekurangan dari strategi yang dimilki oleh KPU kota Padang dalam mensoialisaskan aplikasi 
SiPadlih adalah sosialisasi aplikasi SiPadlih yang dilakukan KPU hanya dalam mengadakan pertemuan dengan beberapa kalangan mayarakat, sehingga penyebaran informasi sosialisasi SiPadlih tidak tersebar secara maksimal. Seharusnya KPU kota Padang juga mensosialisasikannya melalui, media cetak juga, seperti di spanduk, baliho dan poster. Sehingga penyampaian atas adanya aplikasi SiPadllih tidak tersebar secara maskimal dan menyebabkan masih banyak warga kota Padang tidak mengetahui dengan adanya aplikasi SiPadlih. Hal ini dirasa sangat berpengaruh pada efektivitas sosialisasi aplikasi SiPadlih itu sendiri.

Hal ini sejalan dengan hasil penelitian yang dilakukan oleh Ratnamulyani dan Maksudi (2018) tentang Peran Media Sosial Dalam Peningkatan Partisipasi Pemilih Pemula Dikalangan Pelajar di Kabupaten Bogor. Hasil penelitian menemukan adanya berbagai faktor yang mempengaruhi diantaranya karena komunikasi program yang belum optimal.

Keempat, Sarana dan prasarana, dengan tersedianya sarana dan prasarana yang baik maka akan terwujud kinerja yang baik sesuai pula dengan tujuan. Sarana dan prasarana yang dimiliki oleh Komisi Pemiliha Umum kota Padang belum bisa dikatakan baik. Hal ini dibuktikan tidak adanya anggaran khusus untuk mensosialisasikan aplikasi SiPadlih, sehingga pelaksanaan sosialisasi aplikasi SiPadlih tidak dilakukan secara maksimal, seperti sosialisasi aplikasi SiPadih menggunakan media cetak tidak bisa dilakukan karena memang anggarannya yang tidak tersediah. Anggran yang tersediah Rp. 39.600.000 hanya untuk pembuatan aplikasi SiPadlih. Hal ini sangat disayangkan apabila aplikasi SiPadlih yang telah dibuat dengan memakai anggaran yang cukup besar namun sosialisasi dari aplikasi SiPadlih masih minim.

Sejalan dengan penelitian yang dilakukan oleh Sudiarsa dan Putra (2014) perancangan aplikasi sosialisasi pemilihan dan pemungutan suara pemilu legislatif 2014 berbasis teknologi android pada Komisi Pemilihan Umum provinsi Bali. Hasil penelitian tersebut menyatakan bahwa salah satu faktor penghambat pada perancanagan aplikasi sosialisasi pemilihan dann pemungutan suara pemilu legislatif adalah ketersediaan sarana dan prasarana yang tidak memadai untuk menjalankan perancangan aplikasi tersebut.

Kelima, proses analisi dan perumusan sosialisasi, bahwa proses analisis dan perumusan terkait dengan tujuan yang hendak dicapai dan strategi yang telah ditetapkan. Sosialisasi aplikasi SiPadlih masih belum maksimal dilakukan, karena masih banyak masyarakat kota Padang yeng belum mengetahui dengan adanya aplikasi SiPadlih ini, menurut data yang ditemui oleh peneliti hanya sekitar 100 orang yang telah mendownload aplikasi SiPadlih. Hal ini disebabkan strategi sosialisasi yang kurang tepat, sosialisasi hanya dilakukan secara langsung saja, seharusnya dilakukan secara tidak langsung juga, seperti pemanfaatan media cetak, agar sosialisasi aplikasi tersebar secara luas. Tetapi untuk pemanfaatan media iklan tersebut tidak dapat dilakukan, karena tidak adanya anggaran secara khusus untuk sosialisasi aplikasi SiPadlih, anggara yang terseduah hanya untuk pembuatan aplikasinya saja.

\section{Kesimpulan}

Pertama, pelaksanaan sosialisasi aplikasi SiPadlih telah dilaukan bersamaan dengan sosialisasi pilwako seperti biasannya, yaitu dengan cara mengadakan pertemuan dengan macam-macam kalangan masyarakat kota Padang. Tujuan dari pelaksanaan sosialisasi aplikasi SiPadlih yaitu masyarakat akan lebih mudah untuk mencari informasi mengenai pemilihan walikota dan wakil walikota Padang, kemudian penyampaian informasi pemmilihan walikota dan wakil walikota Padang juga tersebar secara luas, dan memudahkan KPU kota Padang dalam menyampaikan informasi sosialisasi pemilihan walokota dan wakil walikota Padang tahun 2018. Namun sangat disayangkan pelaksanaan sosalisasi aplikasi SiPadlih melenceng dari tujuan. hal ini dapat dibuktikan dengan beberapa pendapat masyarakat kota Padang mengenai pelaksanan aplikasi SiPadlih yang penulis temui, bahwasannya masyarakat kota 
Padang masih banyak yang belum mengetahui dengan adanya aplikasi SiPadlih. Kemudian terdapat informasi yang tidak bisa dipahami, seperti dimenu tahapan persiapan dan penyelengaraan, dan dimenu data pemilih, karena infomasi yang dimuat belum terisi.

Kedua, pelaksanaan aplikasi SiPadlih dapat dikatakan belum efektif. Hal ini terbukti masih banyaknya masyarakat kota Padang yang belum mengetahui dengan adanya aplikasi SiPadlih ini, khususnya para masyarakat milenial/warga net sebagai tujuan utama pengadaan aplikasi ini. Hal ini dikarenkaan kegiatan sosialisasi yang belum maksimal yang dilakukan oleh KPU kota Padang, terutama sosialisasi secara tidak langsung mengenai aplikasi SiPadlih, disebabkan tidak adanya anggaran khusus untuk mensosialisasikan aplikasi SiPadlih, sehingga pelaksanaan sosialisasi aplikasi SiPadlih tidak dilakukan secara maksimal.

\section{Daftar Pustaka}

Damsar. (2012). Pengantar Sosiologi Politik. Lampung: Kencana Prenada Efriza. (2012). Sebuah Kajian Ilmu Politik, Bandung: Alfabeta.

Kurniawan, Agung. (2005). Transformasi Pelayanan Publik. Yogyakarta. Pembaharuan Moenir. (2006). Manajemen Pelayanan Umum di Indonesia, Jakarta: PT. Bumi Aksara

Putra, Arry Dharmawan Trissatya. (2016). Inovasi Model Sosialisasi Peran Serta Masyarakat dalam Pemilu. Jurnal Wacana Politik, 5(1)

Ratnamulyani, Maksudi. (2018). Peran Media Sosial Dalam Peningkatan Partisipasi Pemilih Pemula Dikalangan Pelajar Di Kabupaten Bogor. Sosiohumaniora - Jurnal Ilmu ilmu Sosial dan Humaniora, 20, (2): 154 - 161

Sudiarsa, I wayan dan putra, N. A. (2014). Perancangan Aplikasi Sosialisasi Pemilihan dan Pemungutan Suara Pemilu Legislatif 2014 Berbasis Teknologi Android Pada Komisi Pemilihan Umum Provinsi Bali. Jurnal S@ CIES, 5 (1): 49-53

Tangkilisan, Hassel Nogi. (2005). Manajemen Publik. Jakarta: Grasindo

UU No. 9 Tahun 2015 tentang pemerintahan daerah

UU Nomor 8 Tahun 2015 tentang penetapan peraturan pemerintah 